\title{
FREQUENCY VARIANT OF EULER TYPE IDENTITIES AND THE PROBLEM OF SIGN-CONSTANCY OF THE KERNEL IN ASSOCIATED QUADRATURE FORMULAS
}

\author{
I. PERIĆ
}

\begin{abstract}
In the recent years many authors used extended Euler identities to obtain generalizations of some classical quadrature formulas with the best possible error estimates. The main step in obtaining the best possible error estimates was to control zeros of the kernel in the error term which consists of the affine combinations of the translates of periodic Bernoulli polynomials. This was done for some low degrees of Bernoulli polynomials. The main goal of this paper is to consider a general case. The frequency variant of extended Euler identities is found to be more tractable for this problem.
\end{abstract}

Mathematics subject classification (2010): 65D30; 41A50.

Keywords and phrases: Euler identities, Chebyshev systems, General Mean Value theorem, Fourier expansion of Bernoulli functions.

\section{REFERENCES}

[1] LJ. Dedić, M. Matić, J. PeČARIĆ, On generalizations of Ostrowski inequality via some Euler-type identities, Math. Inequal. Appl., 3, 3 (2000), 337-353.

[2] I. Franjić, J. PeČArić, I. Perić, On families of quadrature formulas based on Euler identities, Appl. Math. Comput., 217, 9 (2011), 4516-4528.

[3] I. Franjić, J. PeČArić, I. PERIĆ, Quadrature formulae of Gauss type based on Euler identities, Math. Comput. Modelling., 45 (2007), 355-370.

[4] I. FRANJIĆ, J. PEČARIĆ, I. PERIĆ, General Euler-Ostrowski formulae and applications to quadratures, Appl. Math. Comp., 177 (2006), 92-98.

[5] I. Franjić, J. PeČArić, I. Perić, General Euler-Boole's and dual Euler-Boole's formulae, Math. Inequal. Appl., 8 (2005), 287-303.

[6] R. FRISCH, On approximation to a certain type of integrals, Skandinavisk Aktuarietidskrift, 12 (1929), 129-181.

[7] S. KARLIN, W. J. STUDDEN, Tchebyscheff systems with applications in analysis and statistics, Interscience, New York, 1966.

[8] V. I. KRYLOV, Approximate Calculation of Integrals, Macmillan, New York, London, 1962.

[9] J. PeČArić, I. Perić, A. Vukelić, Sharp integral inequalities based on general Euler two-point formulae, ANZIAM J. 46 (2005), 555-574.

[10] G. PóLYA, On the mean value theorem corresponding to a given linear homogeneous differential equation, Trans. Am. Math. Soc., 24 (1922), 312-324.

[11] G. PólYA, G. SZEGÖ, Aufgaben und Lehrs ätze aus der Analysis II, Berlin, Verlag von Julius Springer, 1925. 